\title{
Nuisance or necessity? Why robust peer review is critical for medical science
}

\author{
Jon Patricios 다, ${ }^{1}$ Joanne Kemp (1) , ${ }^{2}$ Jane S Thornton 다, ${ }^{3}$ \\ Jonathan Drezner (i) ${ }^{4}$
}

\section{WHAT'S IN IT FOR ME?}

The diligent reviewing of submitted manuscripts is not an altogether altruistic pursuit. Perhaps most alluring is the opportunity to read new science before anyone else, at the proverbial cutting edge of the profession. Peer review provides the opportunity to guide and enhance through comments and author revisions the presentation of new findings, so the methods and messages are clear and accurate. You also may be exposed to novel study designs or findings that stimulate your own ideas for novel investigation. Being on a journal's review radar makes you part of a collegial network of academics, scientists and clinicians that may benefit your career as you enhance your credentials and earn collegial respect. The experience gained involves an exchange of opinions between authors, editors and other reviewers that can enhance proficiency as a writer and a scientist. 'Academic Service' forms an increasingly important part of your curriculum vitae and the time may well be recognised by the allocation of continuing professional development points. Or, as a former BJSM editor pithily explained, reviewing should simply be viewed as a 'rite of passage' for clinicians and researchers alike. ${ }^{1}$

\section{WHO BENEFITS?}

Apart from the potential benefits to the reviewer, a well-considered and carefully structured manuscript review is of immense benefit to the author(s). By publication, a paper has usually had at least five pairs of independent critically trained eyes (three peer reviewers, one associate editor, one editor) dissect its content, and possibly up to nine if the full editorial team and a statistical consultant become involved. And

\section{${ }^{1}$ Wits Sport and Health (WiSH), School of Clinical Medicine, Faculty of Health Sciences, Wits University, Johannesburg, Gauteng, South Africa \\ ${ }^{2}$ Sport and Exercise Medicine Research Centre, La Trobe University, Melbourne, Victoria, Australia ${ }^{3}$ Public Health and Family Medicine, University of Western Ontario Schulich School of Medicine and Dentistry, London, Ontario, Canada \\ ${ }^{4}$ Department of Family Medicine, University of Washington, Seattle, Washington, USA}

Correspondence to Professor Jon Patricios, Wits Sport and Health (WiSH), School of Clinical Medicine, Faculty of Health Sciences, Wits University, Johannesburg, Gauteng, South Africa; jpat@mweb.co.za that's before the typesetting and grammar police have a say! In replying to reviewers' comments, it is not unusual for authors to mention that "...the manuscript has benefited significantly from the changes made...”. An editor-in-chief from a different journal recently pronounced that the higher number and standard of papers submitted was largely a result of the excellent panel of reviewers. ${ }^{2}$ The improved manuscript is now of greater value to the journal, its readers and ultimately the profession.

\section{HOW TO REVIEW?}

The failure to include critical article review in formal clinical and scientific training is a gaping void in most medical curricula. This constructive exercise should be an entrenched skill to ensure the passage of critical reasoning and analytics in the evaluation of new science. Some journals themselves provide guidance and examples. ${ }^{34}$ Other informal input may be gleaned from colleagues, editors, research scientists and statisticians. Peer review should always be conducted with respect and reflect the many hours of work performed by the authors in preparing the manuscript. Even when reviewers remain anonymous, approaching the review with the assumption that the authors know your identity will ensure your tone remains collegial and professional.

\section{A credible process}

Benjamin Franklin is credited with the phrase 'If you want something done, ask a busy person...'. There is no setting in which this maxim applies more than manuscript reviews. Experience helps. That time-pressed clinicians and academics still deem peer review a meaningful activity is evidence that they regard it as credible and worthwhile. Credible implies that conflicts of interest are avoided, the process is objective, the review is given the time it deserves, the assessment follows a structure to ensure all important aspects are scrutinised, and, even in the case of a recommendation for 'reject', that feedback is constructive. A review from an experienced pen should serve as a lodestar to help advance science.

\section{METHODS MATTER}

Continuing the BJSM theme of advancing quality research in Sport and Exercise Medicine (SEM), ${ }^{6}$ a methodical approach to conducting a detailed and effective review is needed to achieve a sound result. As a supplement to this editorial, the BJSM Editors provide additional updated guidance for reviewing (online supplemental file 1) that builds on previous work, the journal's requirements, expert input and the latest checklist for statistical assessment. ${ }^{78}$ Increased digitalisation of the review process has streamlined it but also created its own pressures, with deadlines for reviews, revisions and processing, culminating in 'Online First' articles appearing shortly after acceptance (an average of 21 days). A committed reviewer with an efficient system helps to achieve the timely dissemination of new knowledge. BJSM values multiple reviewers for each paper. Importantly, each may have a different skill set and reviewers should always acknowledge gaps in their knowledge. Accurate analysis of the statistical methods in a study is a good example of where specialists provide invaluable input to clinical reviewers, editors and authors.'

\section{The perfect review}

The flawless review probably remains elusive as there will always be an element of subjectivity. Nevertheless, a systematic approach will help promote excellence in the final product. A paper processed for review has already passed an initial screening by the editorial team and is deemed worthy of consideration. A reviewer who dismisses a paper in a few lines has neglected their duty as much as one who casually nods the paper on. Peer review should be viewed as collaborative rather than confrontational. Supporting the paper is not the necessity, but supporting the process is.

Twitter Jon Patricios @jonpatricios, Joanne Kemp @JoanneLKemp, Jane S Thornton @janesthornton and Jonathan Drezner @DreznerJon

Contributors JP and JD conceived the concept of the editorial. JP developed the article framework and design and drafted the original version of the manuscript. Each coauthor contributed to the intellectual content, then critically appraised and revised the draft through three rounds of analysis Each author contributed to the acquisition of relevant information for the supplementary guide, reviewing and editing each over the three iterations. All coauthors approved the final version for submission and take accountability for all aspects of the work.

Funding The authors have not declared a specific grant for this research from any funding agency in the public, commercial or not-for-profit sectors.

Competing interests JD is editor-in-chief of BJSM; JP, JST and JK are editors of BJSM. All coauthors receive honoraria from BMJ.

Patient consent for publication Not required. 
Provenance and peer review Not commissioned; externally peer reviewed.

Supplemental material This content has been supplied by the author(s). It has not been vetted by BMJ Publishing Group Limited (BMJ) and may not have been peer-reviewed. Any opinions or recommendations discussed are solely those of the author(s) and are not endorsed by BMJ. BMJ disclaims all liability and responsibility arising from any reliance placed on the content. Where the content includes any translated material, BMJ does not warrant the accuracy and reliability of the translations (including but not limited to local regulations, clinical guidelines, terminology, drug names and drug dosages), and is not responsible for any error and/or omissions arising from translation and adaptation or otherwise.$$
\text { (2) }
$$$$
\text { OPEN ACCESS }
$$

Open access This is an open access article distributed in accordance with the Creative Commons Attribution Non Commercial (CC BY-NC 4.0) license, which permits others to distribute, remix, adapt, build upon this work non-commercially, and license their derivative works on different terms, provided the original work is properly cited, appropriate credit is given, any changes made indicated, and the use is non-commercial. See: http://creativecommons.org/ licenses/by-nc/4.0/.

(c) Author(s) (or their employer(s)) 2021. Re-use permitted under CC BY-NC. No commercial re-use. See rights and permissions. Published by BMJ.

- Additional material is published online only. To view, please visit the journal online (http://dx.doi.org/ 10.1136/bjsports-2021-104126).

\section{(A) Check for updates}

To cite Patricios J, Kemp J, Thornton JS, et al. Br J Sports Med 2021;55:1063-1064.

Accepted 11 March 2021

Published Online First 22 March 2021

Br J Sports Med 2021;55:1063-1064. doi:10.1136/bjsports-2021-104126

\section{ORCID iDs}

Jon Patricios http://orcid.org/0000-0002-6829-4098 Joanne Kemp http://orcid.org/0000-0002-9234-1923 Jane S Thornton http://orcid.org/0000-0002-35197101

Jonathan Drezner http://orcid.org/0000-0003-35199120

\section{REFERENCES}

1 McCrory P. To review or not to review, that is the question. Br I Sports Med 2002;36:80-1.

2 Lambert M. South African Journal of sports medicine: what happened in 2020 and plans for 2021. S Afr j sports med 2021;33:1-2.

3 Wiley. How to peer review. Available: https:// authorservices.wiley.com/Reviewers/journalreviewers/how-to-perform-a-peer-review/step-bystep-guide-to-reviewing-a-manuscript.html [Accessed 9 Jan 2021]

4 Tandon R. How to review a scientific paper. Asian J Psychiatr 2014;11:124-7.

5 Nielsen RO, Bertelsen ML, Møller M, et al. Methods matter: exploring the 'too much, too soon' theory, part 1: causal questions in sports injury research. Br I Sports Med 2020;54:1119-22.

6 Edouard P, Steffen K, Navarro L, et al. Methods matter: dealing with low compliance in sports injury trials analyses using instrumental variable analysis. Br J Sports Med 2021;55:1006-8.

7 Bjsm. Journal statistics, 2019. Available: https://bjsm. bmi.com/pages/about/ [Accessed 12 Jan 2021].

8 Bjsm. Authors' Guidelines. Available: https://bjsm.bmj. com/pages/authors/ [Accessed 13 Jan 2021].

9 Mansournia MA, Collins GS, Nielsen RO. Checklist for statistical assessment of medical papers: the CHAMP statement. Br I Sports Med 2021;55:1009-17. 